\title{
A perspective on biosolids management
}

\author{
Erik Apedaile BSc(Agr) PAg \\ Environmental Management Services, Ottawa, Ontario
}

W astewater treatment has evolved into an important mechanism that used to protect public health from infectious disease. In the 1850 s, water drawn from the Thames River below London's sewage outfall was found to be a source of a cholera outbreak (1). As a result, 'sewage farms' were established to treat and dispose of wastewater. Gradually, more effective technologies, which required less land, were developed to treat wastewater. The processes of primary and secondary biological treatment eventually eliminated the need for sewage farms in the early part of the past century.

Today, conventional sewage treatment uses chemical and biological processes to separate solids from water in sewage (2). Raw sewage typically moves through a series of processes that, depending upon the plant, include primary, secondary and, in some cases, tertiary treatment. In primary treatment, settleable and floatable solids are removed from the waste flow. In conventional activated sludge secondary treatment, biodegradable dissolved colloidal solids are removed. The solids removed through primary and secondary treatment (primary and secondary sludge) are typically processed in an anaerobic digester, in which putrescible solids are digested into stable organic matter. The solids that result from the digester are known as biosolids, sewage biosolids or, simply, sewage sludge. Biosolids may be further treated through dewatering, heat drying, lime stabilization, composting or other processes. Regardless of the method of treatment, there are few options for end use or ultimate disposal of sewage biosolids. In Canada, approximately 388,700 dry tonnes of biosolids are produced every year (3). About $43 \%$ of these biosolids are applied to land, $47 \%$ are incinerated and $4 \%$ are sent to landfill, with the remainder used in land reclamation and other uses. Land application has been increasing in recent years as many municipalities move away from incineration and landfill disposal due to environmental concerns with these processes. By comparison, the United States and Europe apply approximately $60 \%$ and $34 \%$, respectively, of their biosolids to agricultural land.
Biosolids, for the most part, are provincially regulated in Canada. In Ontario, biosolids are regulated through Regulation 347 of the Environmental Protection Act (4). The Ontario Ministry of Environment uses the Guidelines for the Utilization of Biosolids and Other Wastes on Agricultural Land (5) to assist them in issuing Certificates of Approval. Certificates of Approval are required for all land application sites and include explicit management conditions that are enforceable by the Province under the Environmental Protection Act (4). Biosolids that are sold as a fertilizer may fall under the Agriculture and Agrifood Canada Fertilizer Criteria and the Bureau de Normalization du Quebec Fertilizer Regulation.

Biosolids are used in agriculture because they contain high concentrations of essential crop nutrients, primarily nitrogen and phosphorous. The nutrients are recycled into crop production and are used in place of inorganic fertilizers. Groups opposed to land application of biosolids are primarily concerned about two things: the sources of sewage discharged to municipal sewage treatment plants as well as the presence of pathogens in sewage biosolids. Some groups have argued that biosolids should be first sterilized and then disposed in a sanitary landfill. Their concerns stem from the fact that many municipal sewage treatment plants receive treatable industrial sewage and, in some cases, landfill leachate in addition to domestic sewage. However, it should be noted that all dischargers are regulated through sewer use bylaws to ensure that hazardous wastes are not discharged into sewage treatment systems. Landfill leachate, as with any other discharge, must meet this requirement. Municipal industrial sewer use control programs regulate dischargers through sewer use agreements that are monitored and enforced (6). Industrial source control programs in municipalities across the country have, in large part, been responsible for controlling the quality of biosolids.

Biosolids also contain a variety of pathogens, grouped into bacteria, viruses, protozoa and helminth worms cate- 
gories $(1,7)$. Typically, the densities of these pathogens are reduced two and three orders of magnitude by wastewater treatment and biosolids processing $(2,8)$. This reduction, while significant, leaves appreciable numbers of some organisms in digested sewage biosolids. The pathway for infection by pathogens in biosolids is through direct ingestion, inhalation of bioaerosols or contact of an infectious agent with mucous membranes or damaged skin (8).

While biosolids management practices are designed to prevent exposure to the public through these pathways, a recent study by Dowd et al (9) and the Hazard ID on workers exposed to class B biosolids released by the National Institute of Safety and Health (NIOSH) in the United States (10) have served to elevate public concern about transmission of airborne pathogens. The NIOSH Hazard ID reports that a limited number of air samples collected at land application and storage sites confirms the potential for workers to be exposed to pathogenic organisms and recommends a range of personal protective equipment (ie, gloves and hygienic practices), depending upon the activity in which the worker is engaged. The Dowd risk assessment, based upon computer modelling, concludes that there is some risk of infection to biosolids land application site workers as well as to surrounding residents from storing and land applying biosolids (9). Dowd et al (9) stated that the modelling results represent a worse case scenario and indicated a need for epidemiological screening of biosolids workers.

Conversely, other studies report that the methods used for biosolids land application do not result in airborne release of biological agents to the same extent as in wastewater treatment facilities (11). Waste water treatment workers who are exposed to higher amounts of airborne releases of organisms have not been found to be at higher risk than the general population. A study of the health effects of occupational exposure to wastewater carried out in the United States followed over 100 wastewater treatment plant workers at three activated sludge sewage treatment plants (12). The study included stool examinations, cultures and antibody surveys, and concluded that there was no increased incidence of infection in workers.

There have been a number of epidemiological studies of biosolids land application. One study, looking at human and animal health on 47 farms receiving biosolids and 46 control farms not receiving biosolids in Ohio, concluded that the risks of respiratory or digestive illness, as well as general symptoms, were not significantly different between the biosolids farms and control farms (13). The study used monthly questionnaires concerning general human and animal health, annual tuberculin testing, and quarterly blood and fecal sampling for microbiological testing. The authors concluded that the absence of observed human or animal health effects was due to the controlled application practices that were in accordance with established United States Environmental Protection Agency requirements.

A second study related to the ohio study collected over 300 samples of biosolids from four different sewage treat- ment plants in Ohio and tested them for the presence of viruses (14). Serology methods were then used to measure objectively infection as well as subclinical infection in people on farms where biosolids were used and control farms. Stool specimens were tested for enteric bacterial pathogens. This study did not find a significant difference between biosolids farms and control farms over the five years of the study.

Most of the infectious agents in biosolids are poorly adapted to survival in soil and the environment (7). Soil is an effective filter, by both physically obstructing the movement of bacterial organisms and by adsorbing viruses to soil colloids (15). A number of studies have looked at the potential for contamination of ground and surface waters from sewage biosolids and have found that it is not significant (1). One reason for this is that proper management practices limit the potential for water contamination. It should also be noted that the number of pathogens from human sources added to the soil by biosolids is relatively small compared with the densities of native pathogens present in soil. Fertile soils, which contain protozoa, fungi, slime molds, diatoms, bacteria and viruses, are one of the most microbially active, diverse and dense environments on earth (7).

The issue of biosolids safety is not clear-cut. There are known risks associated with biosolids that must be managed responsibly. It is important to evaluate the risks of biosolids land application in light of other common, widespread agricultural practices such as the land application of animal wastes. When put into this context, the risk of infectious disease to rural residents specifically from biosolids land application appears to be relatively small. Science continues to move forward, but definitive answers will remain elusive. Currently, the balance of evidence supports ongoing land application of biosolids to recycle nutrients and organic matter as a benefit to individual farmers and society as a whole. Health professionals have to participate in the continual improvement of our water supply and wastewater treatment systems.

\section{REFERENCES}

1. National Research Council. Use of Reclaimed Water and Sludge in Food Crop Production. Washington: National Academy Press, 1996.

2. Metcalf and Eddy Inc. Wastewater Engineering, Treatment, Disposal and Reuse. Boston: McGraw-Hill Publishing Company, 1979:430-1.

3. CH2MHill Canada. Biosolids Generation, Treatment, Use and Disposal in Canada. Opportunities for Energy Recovery and Greenhouse Gas Reduction Report. Prepared for Environment Canada, 2000.

4. Environmental Protection Act, Revised Statutes of Ontario, 1990. Toronto: Queen's Printer for Ontario, 1998.

5. Ministry of the Environment and Energy and Ministry of Agriculture, Food and Rural Affairs. Guidelines for the Utilization of Biosolids and Other Wastes on Agricultural Land. Toronto: Queen's Printer for Ontario, 1996.

6. CH2M HILL 1998. Trail Road Landfill Leachate Treatment and Disposal Options. Prepared for Region of Ottawa-Carleton, 1998.

7. Bertucci JJ, Salvador SJ. Microbiology of Sludge in Municipal Sewage Sludge Management: Processing, Utilization and Disposal. Lancaster: Pennsylvania Technomic Publication, 1992. 
8. Sattar SA, Springthorp VS. Are There Any Health Concerns With Handling Biosolids? Ottawa: Faculty of Medicine, University of Ottawa, 1997.

9. Dowd SE, Gerba IL, Pillai SD. Biological transport modeling and risk assessment in relation to biosolids placement. J Environ Qual 2000;29:343-8.

10. United States Department of Health and Human Services. Hazard ID 10: Workers Exposed to Class B Biosolids During and After Field Application, Publication No 2000-158. Washington: United States Department of Health and Human Services, 2000.

11. Rylander R, Lundholm M, Clark CS. Exposure to aerosols of microorganisms and toxins during handling of sewage sludge. In: Wallis PM, HLehmann DL, eds. Biological Health Risks of Sludge Disposal to Land in Cold Climates. Calgary: University of Calgary Press, 1983.

12. Clark CS, Van Meer GL, Linnemann CC Jr, et al. Health effects of occupational exposure to wastewater. In: Pahren $\mathrm{H}$, W Jakubowski, eds. Wastewater Aerosols and Disease -
Proceedings of a Symposium. Ohio: Ohio Office of Research and Development, United States Environmental Protection Agency, 1979.

13. Dorn CR, Reddy CS, Lamphere DN, Gaeuman JV, Lanese R. Health effects of municipal sewage sludge application on Ohio farms. In: Brown RE, ed. Demonstration of Acceptable Systems for Land Disposal of Sewage Sludge Ohio. Washington: United States Department of Commerce, National Technical Information Services, 1985.

14. Hamparian VV, Hughes JH, Ottolenghi FA, Kapral FA, Moeschberger ML, Lanese R. Sludge disposal on farmland: An epidemiologic evaluation of the risk of infection. In: Brown $\mathrm{RE}$, ed.Demonstration of Acceptable Systems for Land Disposal of Sewage Sludge Ohio. Washington: United States Department of Commerce National Technical Information Services, 1985.

15. Gerba CP, Wallis C, Melnick JL. Fate of wastewater bacteria and viruses in soil. J Irrigation Drainage Division 1975;101:157-74 


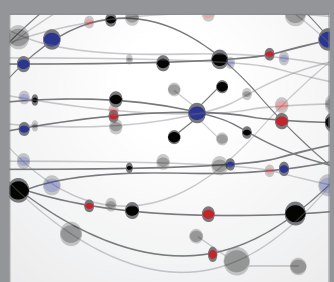

The Scientific World Journal
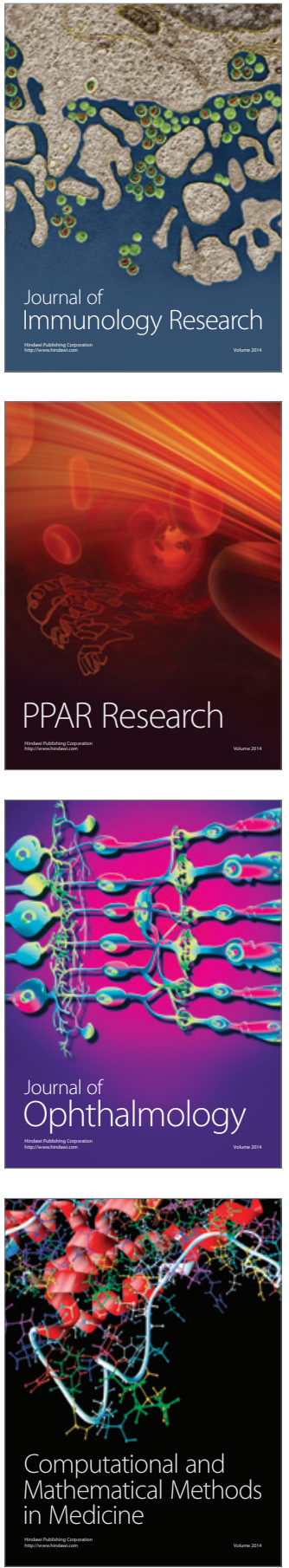

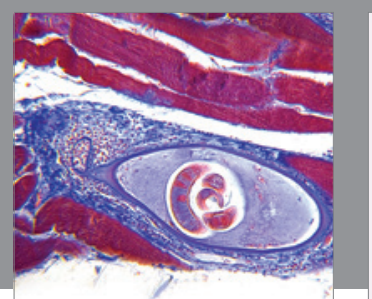

Gastroenterology Research and Practice

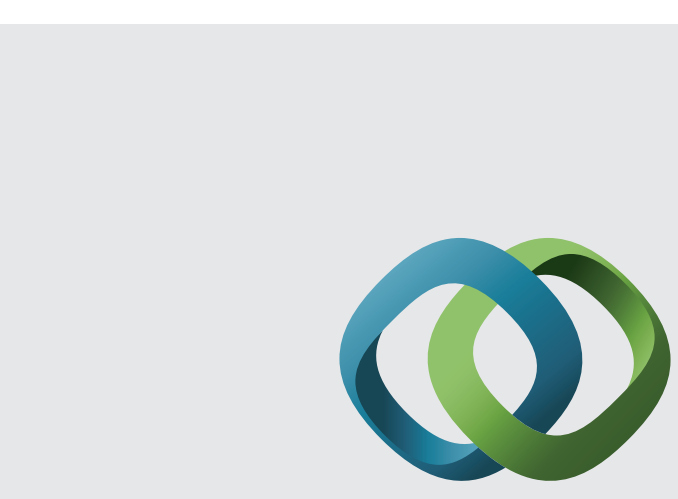

\section{Hindawi}

Submit your manuscripts at

http://www.hindawi.com
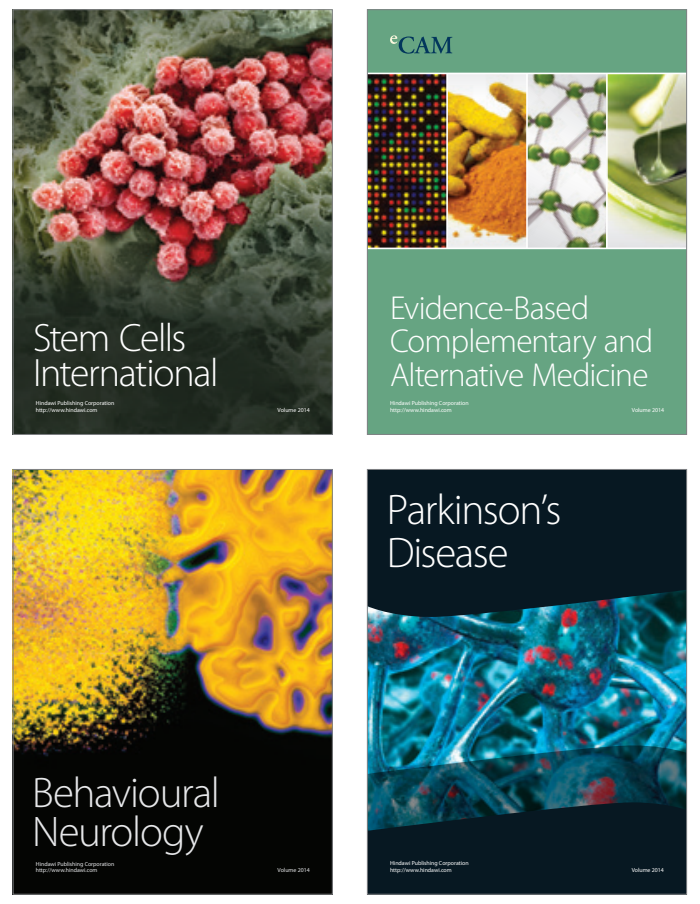
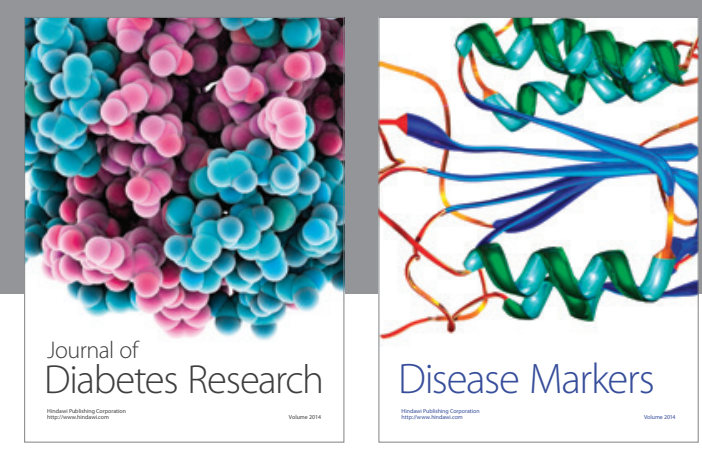

Disease Markers
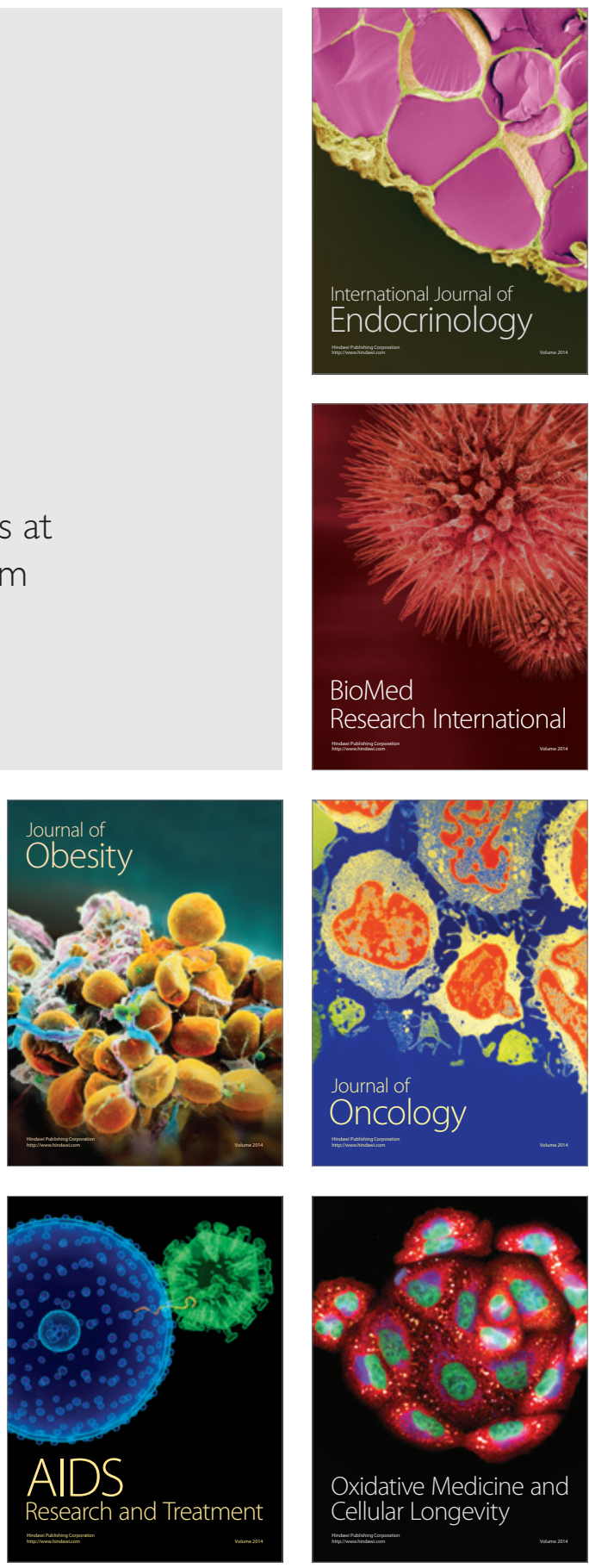